\title{
The Effect of Organizational Culture and Job Satisfaction on Teacher Organizational Commitment of State Junior High School in Tebing Tinggi
}

\author{
Nasrun, Dody Feliks Pandimun Ambaritab \\ Universitas Negeri Medan \\ Medan Indonesia \\ nasrun.nst@gmail.com
}

\begin{abstract}
This study aims to find out: (1) the direct effect of organizational culture on job satisfaction; (2) the direct and indirect effect of organizational culture on teacher organizational commitment; and (3) the direct effect of job satisfaction on teacher organizational commitment. The population in this study were 352 teachers of state junior high school in Tebing Tinggi. In determining the sample, the researcher refers to Arikunto's criteria that is taking 40\% (140 people) of the population. To determine the sample of each school proportional random sampling technique was used. The instruments to collect the data were questionnaires based on the Likert Scale model. The validity was computed using the Product Moment Correlation formula while the reliability was tested using the Alpha Cronbach formula. This causal model was tested using the path analysis. Based on the analysis, it was obtained that: (1) organizational culture had a direct effect on job satisfaction with a path coefficient of 0,$379 ;(2)$ there was a direct and an indirect effect of organizational culture on teacher organizational commitment with a path coefficient of 0,223 and 0,021 ; and (3) job satisfaction had a direct effect on teacher organizational commitment with a path coefficient of 0,215. Based on the results of the study, the three hypotheses enforced are accepted. Therefore, the efforts to improve organizational culture and job satisfaction can increase teacher organizational commitment.
\end{abstract}

Keywords—organizational; culture; job; satisfaction, commitment

\section{INTRODUCTION}

Junior High School is formal educational institution that provide education for students graduated from Elementary School so that graduates have the ability to continue education to Senior High School/ Vocational High School. Junior High Schools as an organization requires teachers who have commitment to the organization to achieve school goals effectively and efficiently.

Organizational commitment refers to someone's promise or responsibility toward the organization to work as the wishes of the organization and to achieve organizational goals effectively and efficiently. According to Sopiah (2008:155) organizational commitment is the identification and strong involvement of someone against the organization. This is in line with the concept adapted from the opinion of Blau and Boal (as cited in: Sopiah, 2008:155) which stated that organizational commitment is an alignment between employee loyalty to the organization and organizational goals. With high commitment, individuals will care about the future of the organization and try to make the organization better. Conversely, individual with low commitment will consider his/ himself or his/ her group to be important and has no desire to make the organization better. Futhermore, according to Prayitno (2009:219) that commitment can be interpreted as a promise to do something seriously. While, Schatz and Schatz (1995:67) suggested that commitment is the most fundamental thing for everyone in his/ her job; without any commitment, the tasks assigned to him/his are difficult to be done properly.

Commitment to the organization will create individual sequacity against organizational rules. Sequacity with the organization will facilitate the implementation of school programs and policies. Sequacity or loyalty to the organization will not make a person turn over intention (move); a disease that lately occurs in many educational units. Many teachers move from one school to another, even teachers labeled as Civil Servant (PNS) do turn over intention to schools in urban areas.

The Indonesian Corupption Watch (ICW) study (in CNNindonesia.com) mentions that many civil servant teachers are piled up in schools in urban areas, while schools in remote areas are still short of teachers. In this research, ICW conducted an evaluation on the implementation of the Decree of five ministers on the regulation and equity of civil servant teachers in Indonesia. From there, ICW concluded that the regulation and equity of teachers have failed to reach the target.

The phenomenon of the larger number of teachers who make the move from one organization to the others causes problems to the policy of teacher distribution. The process of recruitment and placement of teachers through various formations, either the levitation formation through honorary or the teacher acceptance test in various districts/ cities is 
very good in solving the lack of teacher in various areas, but in the implementation, after several years, many teachers who pass the test or have been appointed as civil servant have moved to urban areas. The turn over intention indicates the absence of a teachers' organizational commitment to the organization. Without any commitment to the organization, the teacher will not stand in the organization.

Based on the description above, it is necessary to conduct research to examine the organizational commitment and the variables that influenced it i.e. organizational culture and job satisfaction.

\section{THEORITICAL FRAMEWORK}

\section{A. Organizational Culture}

Mangkunegara (2008:113) said that organizational culture is the set of assumptions or belief systems, values and norms that are developed in the organization as behavioral guidelines for its members to resolve external adaptation and internal integration issues. Furthermore, according to Newstrom (as cited in Ambarita, et al., 2014:7) organizational culture is the set of assumptions, beliefs, values, and norms that are shared by organization members. In line with this, Robbins and Judge (2011:521) stated that organizational culture is a system of shared meaning held by members that distinguishes the organization from other organizations. Further, Robbins and Judge (2009:608) made the correlation model of organizational culture with performance and satisfaction, as seen in the Figure 1.

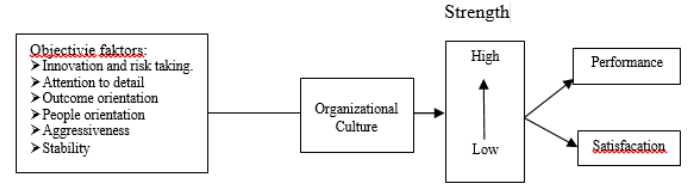

Figure 1. Correlation Model of Organizational Culture with Performance and Satisfaction

Based on the Figure 1, it can be explained that the organizational culture directly affects satisfaction and performance.

While according to Colquitt, et al. (2009:64) organizational commitment can be affected by organizational mechanisms, group mechanisms, individual characteristics, and individual mechanisms, as seen in the following figure.

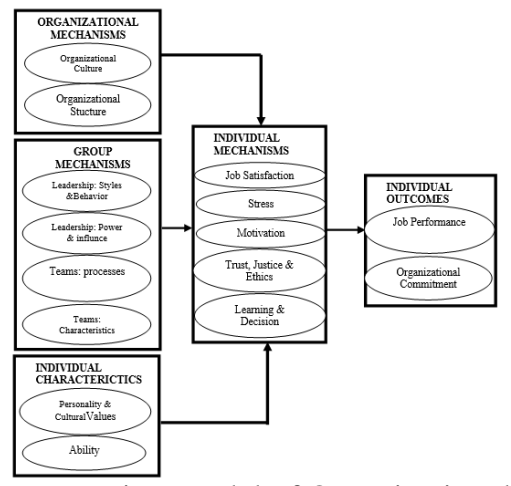

Figure 2. Integrative Model of Organizational Behavior
Based on the Figure 2, it can be explained that organization commitment can be affected by job satisfaction, and job satisfaction can be affected by organizational culture

\section{B. Job Satisfaction}

McShane and Von Glinow (2010:108) stated that job satisfaction as one's evaluation of his/ her work, work environment, and emotional experience in the job. Furthermore, according to Luthans (2006:243) job satisfaction is a happy emotional condition or positive emotion that come from a job assessment or work experience. Job satisfaction is the result of employees' perceptions of how well their work based on the things that are judged important. While, Porter (as cited in Ardana, et al., 2008:23) says that job satisfaction is the difference of something that should exist with something that actually exist (factual). The smaller the gap between the two condition, the more satified the person will be.

\section{Organizational Commitment}

According to Snyder, Dowd and Houghton (1994:128) the term commitment comes from the Latin word "Committere" which means combining, uniting, believing and doing. Furthermore, Luthans (2006:249) stated that organizational commitment is an attitude that shows employee loyalty and is an ongoing process of how an organization member expresses their attention to the success and goodness of the organization. While, George and Jones (2002:391) affirmed that organizational commitment is a collection of feelings and beliefs that each member of the organization has about its organization as a whole.

\section{Hypothesis of the study}

The hypothesis were formulated as follows: (1) organizational culture (X1) had a direct positive effect on teachers job satisfaction (X2) of state junior high school in Tebing Tinggi; (2) organizational culture (X1) had a direct positive effect on teacher organizational commitment (X3) of state junior high school in Tebing Tinggi; and (3) teacher job satisfaction (X2) had a direct positive effect on teacher organizational commitment (X3) of state junior high school in Tebing Tinggi.

\section{RESEARCH METHODS}

This study is a causal research which is designed to explain causal relationship between organizational culture and job satisfaction toward teacher organizational commitment of state junior high school in Tebing Tinggi, Indonesia.

The population in this study were all teachers of public junior high school in Tebing Tinggi with the number of 352 people. In determining the number of samples, $40 \%$ of the population (Arikunto, 2008:116) and proportional random sampling technique was used. Thus, it was obtained 140 sample, as seen in the Table 1. 
Table 1. Distribution of Sample of Public Junior High School in Tebing Tinggi

\begin{tabular}{|c|c|c|}
\hline No. & Name of School & Sample \\
\hline 1 & SMP Negeri 1Tebing Tinggi & $40 / 100 \times 50=20$ \\
\hline 2 & SMP Negeri 2 Tebing Tinggi & $40 / 100 \times 32=13$ \\
\hline 3 & SMP Negeri 3 Tebing Tinggi & $40 / 100 \times 46=18$ \\
\hline 4 & SMP Negeri 4 Tebing Tinggi & $40 / 100 \times 40=16$ \\
\hline 5 & SMP Negeri 5 Tebing Tinggi & $40 / 100 \times 44=18$ \\
\hline 6 & SMP Negeri 6 Tebing Tinggi & $40 / 100 \times 36=14$ \\
\hline 7 & SMP Negeri 7 Tebing Tinggi & $40 / 100 \times 30=12$ \\
\hline 8 & SMP Negeri 8 Tebing Tinggi & $40 / 100 \times 36=14$ \\
\hline 9 & SMP Negeri 9 Tebing Tinggi & $40 / 100 \times 30=12$ \\
\hline 10 & SMP Negeri 10 Tebing Tinggi & $40 / 100 \times 8=3$ \\
\hline \multicolumn{2}{|c|}{ Total } & 140 \\
\hline
\end{tabular}

The instrument for collecting the data were questionnaires based on Likert Scale model of which validity and reliability had been tested. The validity was computed using the Product Moment Correlation formula while the reliability was tested using the Alpha Cronbach formula. This causal model was tested using the path analysis. The path analysis was done to confirm the views by Schumacker, R. \& Lomax, R. (as cited in: Riadi, 2013:3) that stated "path analysis is an extension of multiple regression models or equations can be estimated simultaneously; it provides a more effective and direct way of modelling effects. Path analysis can be considered an early form and special case of structural equation modelling in which structural among only observed variables". The causal relationship between variables can be described as follows.

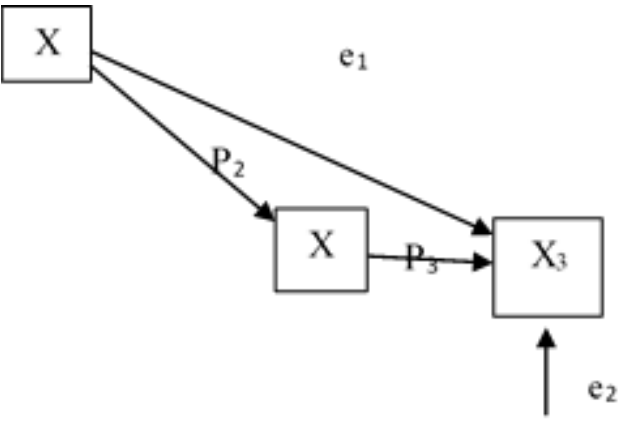

Figure 3. The Causal Relationship Between Variables

\section{RESEARCH FINDING AND DISCUSSION}

\section{A. Validity and Reliability}

Based on the result of testing, the validity of items of each instrument is seen in Table 2 below.

Table 2. Validity of Items of Each Instrument

\begin{tabular}{|l|c|c|c|}
\hline \multicolumn{1}{|c|}{ Variable } & $\begin{array}{c}\text { Total } \\
\text { Items } \\
\text { Tested }\end{array}$ & $\begin{array}{c}\text { Items } \\
\text { Not } \\
\text { Valid }\end{array}$ & $\begin{array}{c}\text { Items } \\
\text { Valid }\end{array}$ \\
\hline $\begin{array}{l}\text { Organizational } \\
\text { Culture }\end{array}$ & 36 & 6 & 30 \\
\hline Job Satisfaction & 35 & 5 & 30 \\
\hline $\begin{array}{l}\text { Organizational } \\
\text { Commitment }\end{array}$ & 40 & 10 & 30 \\
\hline
\end{tabular}

Based on the reliability test, the instrument is measured to be reliable if $\alpha>0,60$. The reliability test result is illustrated in Table 3 .

Table 3. Reliability Test Result

\begin{tabular}{|l|c|c|c|}
\hline \multicolumn{1}{|c|}{ Variable } & $\begin{array}{c}\text { Total } \\
\text { Items }\end{array}$ & $\boldsymbol{\alpha}$ & Explanation \\
\hline Organizational Culture & 30 & 0,939 & Reliable \\
\hline Job Satisfaction & 30 & 0,939 & Reliable \\
\hline $\begin{array}{l}\text { Organizational } \\
\text { Commitment }\end{array}$ & 30 & 0,956 & Reliable \\
\hline
\end{tabular}

\section{B. Data Description}

The data description of three variables is presented in Table 4.

Table 4. Data Description of Three Variables

\begin{tabular}{|c|c|c|c|c|}
\hline \multirow{2}{*}{ No } & \multirow{2}{*}{$\begin{array}{c}\text { Descriptive } \\
\text { Statistic }\end{array}$} & \multicolumn{3}{|c|}{ Variable } \\
\cline { 3 - 5 } & Sample & $\mathbf{X}_{\mathbf{1}}$ & $\mathbf{X}_{\mathbf{2}}$ & $\mathbf{X}_{\mathbf{3}}$ \\
\hline 1. & Mean & 99,95 & 106,48 & 99,42 \\
\hline 2. & Median & 100 & 106 & 99 \\
\hline 3. & Mode & 90 & 100 & 90 \\
\hline 4. & Variance & 268,63 & 196,84 & 167,70 \\
\hline 5. & Standard Deviation & 16,39 & 14,03 & 12,95 \\
\hline 6. & Range & 58 & 58 & 49 \\
\hline 7. & Maximun Score & 129 & 128 & 120 \\
\hline 8. & Minimum Score & 71 & 70 & 71 \\
\hline 9. & Sum & 13993 & 14907 & 13919 \\
\hline 10 & \multicolumn{4}{|c}{ Jsnxk } \\
\hline
\end{tabular}

\section{Hypothesis Testing}

After the path analysis was done, the path coefficient was used to test the research hypothesis. The criteria that was used in testing the hypothesis is if the path coefficient less than 0,05 then the path was meaningless.

Table 5. Description of Path Coefficient and Significance

\begin{tabular}{|c|c|c|c|}
\hline $\begin{array}{c}\text { Path } \\
\text { Coefficient }\end{array}$ & $\mathbf{t}_{\text {count }}$ & $\mathbf{t}_{\text {table }}$ & Description \\
\cline { 3 - 3 } & & $\boldsymbol{\alpha}=\mathbf{0 , 0 5}$ & \\
\hline $\mathrm{P}_{21}=0,379$ & 4,8111 & 1,645 & Significant path \\
\hline $\mathrm{P}_{31}=0,223$ & 2,6836 & 1,645 & Significant path \\
\hline $\mathrm{P}_{32}=0,215$ & 2,5898 & 1,645 & Significant path \\
\hline
\end{tabular}

Based on the description in the Table 5, it was found that the value of tcount of three path coefficients was greater than ttable at $\alpha=0,05$. So, it can be concluded that the three path coefficients were significant.

Table 6. Description of Path Coefficient,

Direct Effect and Indirect Effect of the Exogenous on the Endogenous

\begin{tabular}{|c|c|c|c|}
\hline $\begin{array}{c}\text { Variable } \\
\text { Effect }\end{array}$ & \multicolumn{2}{|c|}{ Causal Effect } & \multirow{2}{*}{ Total } \\
\cline { 2 - 3 } & Direct Effect & $\begin{array}{c}\text { Indirect Effect } \\
\text { through } \mathbf{X}_{2}\end{array}$ & \\
\hline $\mathrm{X}_{1}-\mathrm{X}_{2}$ & 0,379 & & 0,379 \\
\hline $\mathrm{X}_{1}-\mathrm{X}_{3}$ & 0,223 & $\begin{array}{c}0.223 \times 0.215 \times \\
0.438=0.021\end{array}$ & 0,244 \\
& & & 0,215 \\
\hline $\mathrm{X}_{2}-\mathrm{X}_{3}$ & 0,215 & & \\
\hline
\end{tabular}

Based on the description above, it was concluded that the direct effect of Organizational Culture (X1) on Job Satisfaction (X2) is 0,379. The direct effect of 
Organizational Culture (X1) on Organizational Commitment (X3) is 0,223 . The direct effect of Job Satisfaction (X2) on Organizational Commitment (X3) is 0,215. The indirect effect of Organizational Culture (X1) on Organizational Commitment (X3) through Job Satisfaction (X2) is 0,021.

\section{Discussion}

1. The Effect of Organizational Culture on Job Satisfaction

The research findings show that the oganizational culture had a direct effect on job satisfaction with a path cofficient of 0,379 or $14,36 \%$. It means that $14,36 \%$ of the effect on job satisfaction can be influenced by the oganizational culture, while the rest of $85,64 \%$ is determined by other variables. This finding supports the opinion of Robbins and Judge (2009:608) and Colquitt, LePine, and Wesson (2009:64).

2. The Effect of Organizational Culture on Organizational Commitment

Based on the findings, it was revealed that there was a direct effect of organizational culture on organizational commitment at the value of 0,223 or $4,97 \%$. This means that $4,97 \%$ of the effect on organizational commitment was influenced by the oganizational culture and $95,03 \%$ is affected by other variables. This finding answers the opinion of Colquitt, LePine, and Wesson (2009:64).

3. The Effect of Job Satisfaction on Organizational Commitment

The research findings show that job satisfaction had a direct effect on organizational commitment with a path coefficient of 0,215 or $4,62 \%$. It means that $4,62 \%$ of the effect on organizational commitment can be influenced by job satisfaction, while the rest of $95,38 \%$ is determined by other variables. This finding supports the opinion of Colquitt, LePine, and Wesson (2009:64).

\section{CONCLUSIONS AND RECOMMENDATIONS}

A. Conclusions

Based on the previous descriptions, if can be concluded that:

a) Organizational culture had a positive direct effect on job satisfaction. The value of the direct contribution of organizational culture on job satisfaction is 0,379 or $14,36 \%$. The rest of $85,64 \%$ is determined by other variables.

b) Organizational culture had a positive direct effect on organizational commitment. The value of direct contribution of organizational culture on organizational commitment is 0,223 or $4,97 \%$. The $95,03 \%$ is affected by other variables. c) Job satisfaction has a positive direct effect on organizational commitment. The value of direct contribution of job satisfaction on organizational commitment is 0,215 or $4,62 \%$. The remaining $95,38 \%$ is affected by other variables.

\section{B. Recommendations}

Based on the conclusions, several suggestions are proposed. Effort that can be done is as follows:

a) The improvement of organizational commitment can be done by: a) have a strong desire to survive as members of the organization; and b) desire to strive toward the achievement of organizational goals.

b) To increase job satisfaction can be done by: (1) designing the work to be fun and exciting; (2) giving fair rewards, benefits and promotion opportunities; and (3) adjusting work with one's interests and expertise.

\section{REFERENCES}

[1] Ambarita, Biner, dkk. 2014. Perilaku Organisasi. Bandung: Alfabeta.

[2] Ardana, K., Mujiati, N.W., Sriathi, A.A.A. 2008. Perilaku Keorganisasian. Yogyakarta: Graha Ilmu.

[3] Arikunto, Suharsimi. 2008. Prosedur Penelitian Suatu Pendekatan Praktek. Jakarta: PT. Rineka Cipta.

[4] Colquitt, Jason A., Jeffry A. LePine, Michael J. Wesson. 2009. Organizational Behavior: Improving Performance and Commitment in The Workplace. New York: McGraw-Hill Companies.

[5] Http://www.cnnindonesia.com/nasional/20141222133801-2019743/icw-guru-menumpuk-di-kota-pemerataan-gagal, diunduh $\operatorname{tgl} .30 / 03 / 2016$

[6] Luthans, F. 2006. Perilaku Organisasi, Edisi Sepuluh. Yogyakarta: Penerbit Andi.

[7] Mangkunegara, Anwar Prabu. 2008. Perilaku dan Budaya Organisasi. Bandung: Refika Aditama.

[8] McShane, Steven and Mary Ann Von Glinow. 2010. Organizational Behavior - Emerging Knowledge and Practice For The Real World 5th Edition. New York: McGraw-Hill Companies, Inc.

[9] Prayitno. 2009. Dasar Teori dan Praksis Pendidikan. Jakarta: Gramedia.

[10] Riadi, Edi. 2013. Aplikasi Lisrel untuk Penelitian Analisis Jalur. Yogyakarta: CV. ANDI OFFSET.

[11] Robbins, Stephen P. and Timothy A. Judge. 2009. Organizational Behavior. New Jersey: Pearson Education, Inc.

[12] 2011. Organizational Behavior. New Jersey: Pearson Education, Inc.

[13] Schatz, K. and L. Schatz. 1995. Managing by Influence. New Jersey: Prentice Hall, Inc.

[14] Snyder, Neil H., James J. Dowd, Jr., Dianne Morse Houghton. 1994. Vision, Values and Courage, Leadership for Quality Management. New York: The Press.

[15] Sopiah. 2008. Perilaku Organisasional. Yogyakarta: Penerbit Andi Offset.

[16] George, Jennifer M. and Gareth R. Jones. 2005. Understanding and Managing Organizational Behavior, Fifth Edition. Upper Saddle River: Pearson Prentice Hall 